\title{
TEMPERATURE GRADIENTS IN THE ANTARCTIC ICE SHEET
}

\author{
By Malcolm Mellor \\ (Meteorology Department, University of Melbourne*)
}

\begin{abstract}
Measurements of ice temperature to depths of $30-40 \mathrm{~m}$. are given for a number of points on the ice sheet in MacRobertson Land. Variations of mean surface temperature with elevation and with latitude, and the temperature gradients below a depth of $15 \mathrm{~m}$. are compared with results from other parts of Antarctica and from Greenland. Explanations of negative temperature gradients near the surface of ice sheets are reviewed, and an equation derived by Robin is checked against the measurements following its recent justification from conduction theory. Surface ice velocities necessary for development of the observed temperature gradients are computed, and these values are then compared with ice velocities estimated independently from flow measurements at the coast and continuity considerations. It is found that, if negative gradients are attributed solely to the Robin effect, improbably high ice velocities are called for, and so climatic change is reconsidered. Some evidence of secular warming in Antarctica is mentioned and a recent numerical solution of the conduction equation for the surface-warming case is described. It is concluded that the measured temperature profiles can be explained reasonably by climatic amelioration.
\end{abstract}

RÉsumé. On donne des mesures de la température de la glace, observées en un certain nombre d'endroits, et jusqu'à des profondeurs de 30-40 m, sur l'inlandsis de Mackobcrtson Land. On cite les variations dans les températures moyennes superficielles suivant l'élévation et la latitude, et aussi les gradients des températures à des profondeurs en dessous de $15 \mathrm{~m}$, et on les confronte avec des observations pareilles faites dans d'autres régions de l'Antarctique et au Groenland. On passe en revue les théories suggérées pour expliquer les gradients thermiques négatifs constatés près de la surface des inlandsis; et en l'appliquant aux mesures observées on a contrôlé une équation établie par Robin à laquelle unc justification a récemment été fournie par la théorie de la conduction de la chaleur. Les vitesses de mouvement de la glace superficielle qui étaient indispensables pour établir les gradients thermiques ont été calculées: on a ensuite comparé ces valeurs avec des vitesses de mouvement déduites indépendamment de ces calculs et basées sur des mesures de l'écoulement sur la côte, en présumant la continuité de cet écoulement. On a trouvé qu'il faut présumer des mouvements d'une vitesse invraisemblable si l'on explique les gradients négatifs uniquement par l'effet Robin; ainsi a-t-on examiné à nouveau la question des changements climatiques. On cite quelques indications du réchauffement séculaire dans l'Antarctique, et on décrit une solution numérique récemment trouvée à l'équation sur la conduction qui s'applique aux conditions de réchauffement superficiel. On en conclut que les profils des températures observées se laissent vraisemblablement expliquer par l'amélioration des conditions climatiques.

Zusammenfassung. Gemessene Eistemperaturen bis zu 30-40 m Tiefe werden fur eine Anzahl Punkte des Inlandeises in MacRobertson Land mitgeteilt. Änderungen der mittleren Oberflächentemperaturen mit Meereshöhe und geographischer Breite und die Temperaturgradienten in mehr als $15 \mathrm{~m}$ Tiefe werden mit Resultaten aus andern Teilen der Antarktis und aus Grönland verglichen. Erklärungsversuche für negative Temperaturgradienten nahe der Oberfläche von kontinentalen Eisdecken sind zusammengefasst und eine von Robin entwickelte Gleichung deren Berechtigung kürzlich durch Anwendung der Wärmeleitungstheorie bestätigt werden konnte, wird durch Einsetzen von Messergebnissen überprüft. Bewegungsgeschwindigkeiten an der Oberfläche, die nötig wären, um den beobachteten Temperaturgradienten zu bilden, werden berechnet und mit Schätzungen verglichen, die unabhängig von den Temperaturmessungen aus den beobachteten Bewegungen an der Küste und Kontinuitätsbedingungen erhalten sind. Falls die negativen Temperaturgradienten lediglich dem Robin-Effekt zugeschrieben werden, ergeben sich unwahrscheinlich hohe Bewegungsgeschwindigkeiten, weshalb Klimaänderungen in Wiedererwägung gezogen werden. Anzeichen säkularer Erwärmung der Antarktis werden mitgeteilt und eine neulich entwickelte numerische Lösung der Leitungsgleichung für den Fall der Oberflächenerwärmung wird beschrieben. Es wird geschlossen, dass das gemessene Temperaturprofil durch Klimaverbesserung befriedigend erklärt werden kann.

\section{INTRODUCTION}

In the southern summer of $1957-58$ a field party of the Australian National Antarctic Research Expeditions made a $600 \mathrm{~km}$. seismic traverse on the ice sheet south of Mawson station and also carried out glaciological observations. The work produced a meridional profile of the ice surface and its rock base in long. $62^{\circ} \mathrm{O}^{\prime} \mathrm{E}$. and a record of surface conditions on the ice sheet.

Glaciological measurements included vertical profiles of ice temperature to a depth of about $30 \mathrm{~m}$. for twelve points on the traverse. Since seasonal variations of air temperature

* Now at U.S. Army Snow, Ice and Permafrost Research Establishment. 
become indistinct at a depth of about 10-1 $5 \mathrm{~m}$., the ice temperature at that depth is close to the annual mean air temperature at any point on the ice sheet. Below the ${ }_{5} 5 \mathrm{~m}$. level temperature profiles begin to give some indication of the temperature distribution within the ice sheet.

\section{Measuring Methods}

A simple electrical resistance thermometer with a balanced Wheatstone bridge circuit was used for the work. The instrument was originally used for measuring air temperatures from Spitfire aircraft and was graduated in degrees Centigrade. Readings could be estimated to $0 \cdot \mathrm{I}^{\circ} \mathrm{C}$. owing to the balanced bridge arrangement. The temperature-sensitive element (type Weston No. I 1 20643) was attached to the end of a long lead which also contained a dummy compensating lead. The length of the cable was marked with tags attached at $3.05 \mathrm{~m}$. ( $10 \mathrm{ft}$.) intervals. The thermometer was lowered down $10 \mathrm{~cm}$. diameter boreholes drilled with a diesel-hydraulic flight auger, and readings were taken with the bulb in gentle contact at the side of the hole. Before and after each set of measurements the instrument was calibrated by burying the sensitive element and a mercury-in-glass thermometer in close contact under the surface snow. Bottom temperatures in the holes were occasionally checked with an insulated mercury, or xylol, thermometer raised rapidly after long "soaking". The low precision of the electrical thermometer made it necessary to measure temperatures at each level three times to obtain a reliable mean value.

\section{FORM OF THE ICE SHEET}

It will be argued later that temperatures on, and inside, an ice sheet are dependent to some extent on the shape of the ice sheet, and it may be well to mention here a few points concerning surface forms.

For $300 \mathrm{~km}$. south of Mawson the ice sheet rises with a progressively decreasing surface slope; if local disturbances are ignored the ice cap profile can be represented reasonably accurately by an ellipse, which for MacRobertson Land generally might take the form ${ }^{\mathrm{I}}$

$$
h=4\left\{1-\left(\frac{r}{1400}\right)^{2}\right\}^{\frac{1}{3}}
$$

where $h$ is the height of the surface at any radius $r$ (measured from the "centre" or highest point). The units are kilometres.

In actual fact the profile along the 62 nd meridian is strongly influenced by a huge valley situated some $200 \mathrm{~km}$. to the east and ice movement south of lat. $69^{\circ} \mathrm{S}$. has a predominant eastward component. In Figure I form lines have been sketched on an outline map to give some impression of the topography, whilst Figure 2 shows the ice sheet profile along the meridian $62^{\circ} \mathrm{O} 5^{\prime} \mathrm{E}$. together with the idealized profile according to equation ( $\mathrm{I}$ ).

\section{Results}

Typical temperature profiles measured during the $1957-5^{8}$ journey from Mawson are given graphically in Figure $3^{*}$ and the temperature gradients below the $15 \mathrm{~m}$. level are listed later in Table II.

The temperature at $15 \mathrm{~m}$. depth can be taken as a measure of the annual mean air temperature at the surface; ice temperatures for this level have been plotted against surface elevation and against distance from the coast in Figures 4 and 5 respectively, in order to show the surface temperature variations with altitude and latitude.

Between $o$ and $1,000 \mathrm{~m}$. a.s.l. the surface temperature change with altitude is about $0 \cdot 9^{\circ} \mathrm{C}$. $/ 100 \mathrm{~m}$., between $\mathrm{I}, 000$ and $2,000 \mathrm{~m}$. a.s. 1 . it is $\mathrm{I} \cdot \mathrm{I}^{\circ} \mathrm{C}$. $/ \mathrm{I}$ oo m., and above $2,000 \mathrm{~m}$.
the lapse is approximately $\mathrm{I} \cdot 3^{\circ} \mathrm{C}$. $/ 100 \mathrm{~m}$. On the ice cap south of "Mirnyy", Bogoslovski ${ }^{2}$

* Copies of all the profiles are filed at I.G.Y. Data Centres. 


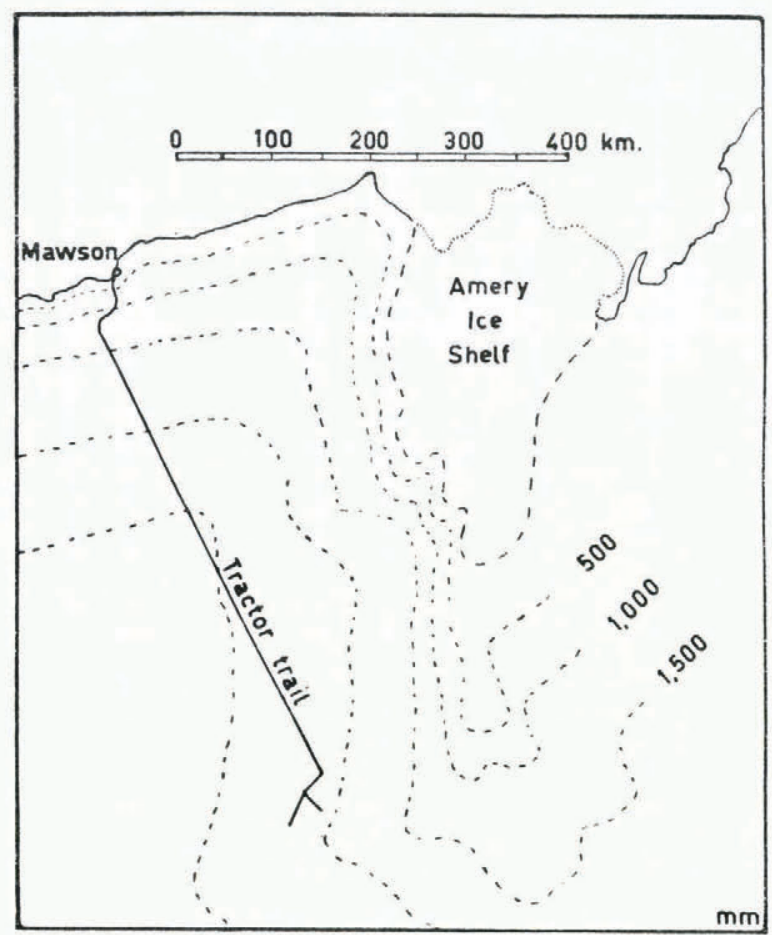

Fig. I. Map showing the tractor trail and form lines of the ice sheet

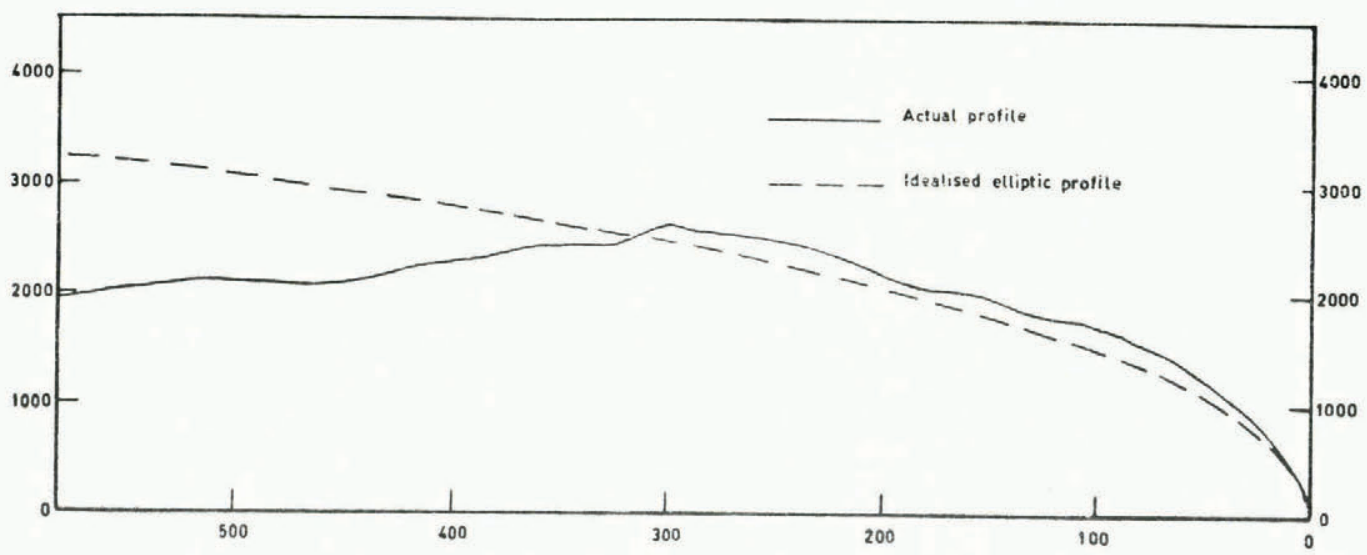

Fig. 2. Surface profile of the ice sheet along the meridian $62^{\circ} 05^{\prime} \mathrm{E}$. 


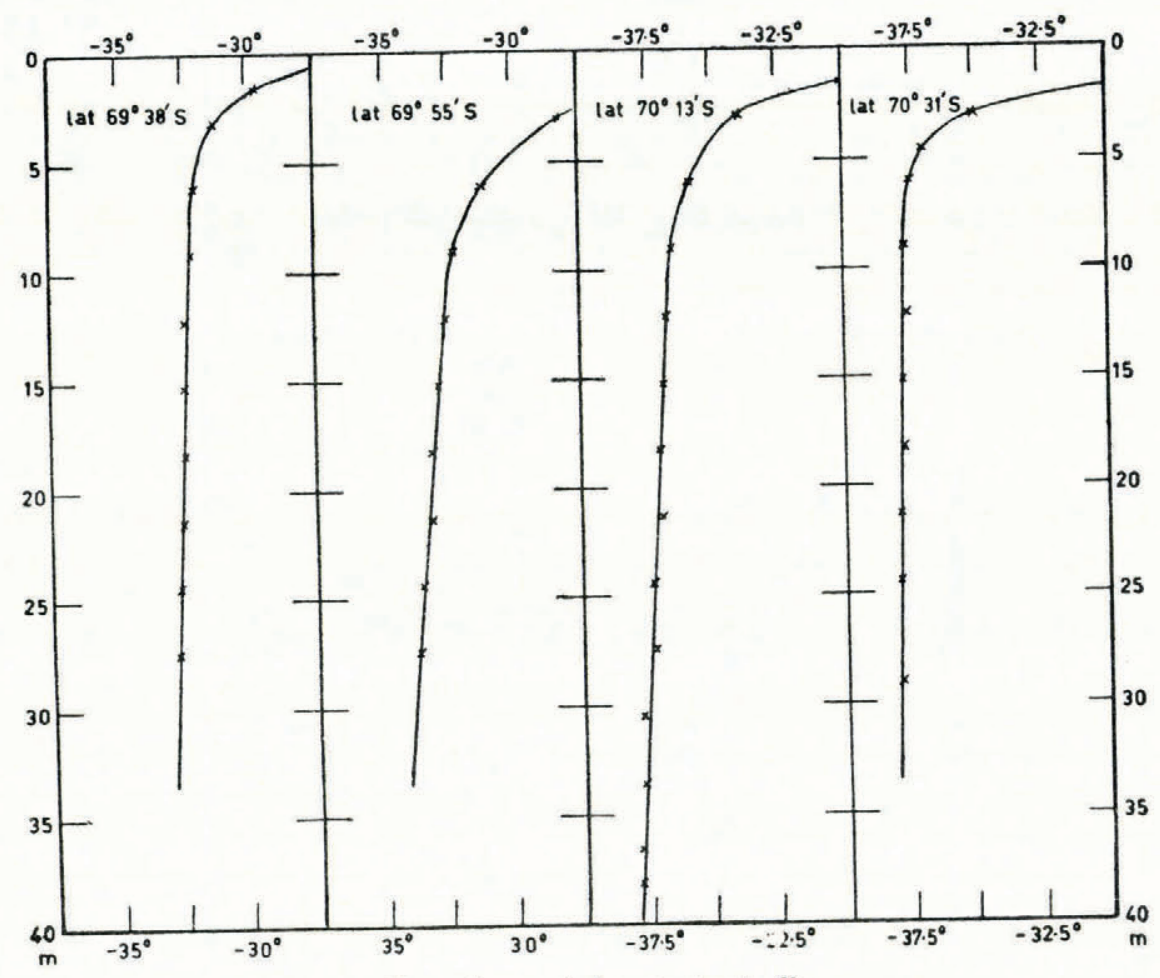

Fig. 3. Some typical temperature profiles

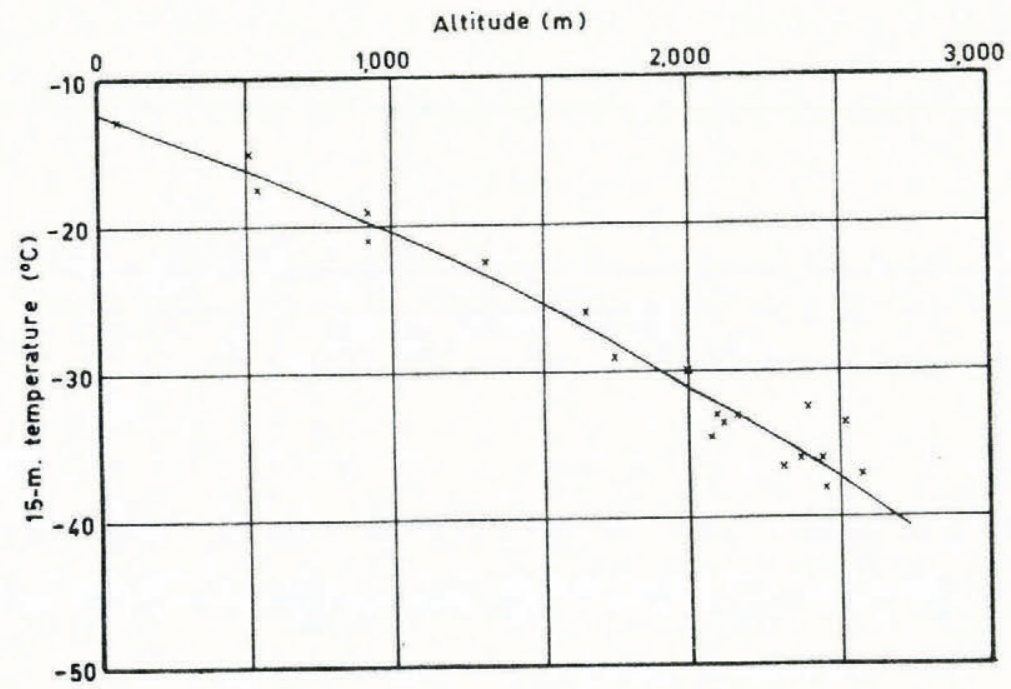

Fig. 4. Variation of ice temperalure $15 \mathrm{~m}$. below the surface with altitude above sea-level 
found a change of $1 \cdot 05^{\circ} \mathrm{C}$. $/ 100 \mathrm{~m}$. between $\mathrm{o}$ and $2,000 \mathrm{~m}$. a.s.l. and $\mathrm{I} \cdot 27^{\circ} \mathrm{C} . / 100 \mathrm{~m}$. between 2,000 and $3,500 \mathrm{~m}$.

From Figure 5 the mean surface temperature variation with latitude appears to be about $\mathrm{I}^{\circ} \mathrm{C}$. $/ 100 \mathrm{~km}$., or approximately $0.9^{\circ} \mathrm{C}$. per degree of latitude, between $69^{\circ} \mathrm{S}$. and $73^{\circ} \mathrm{S}$.

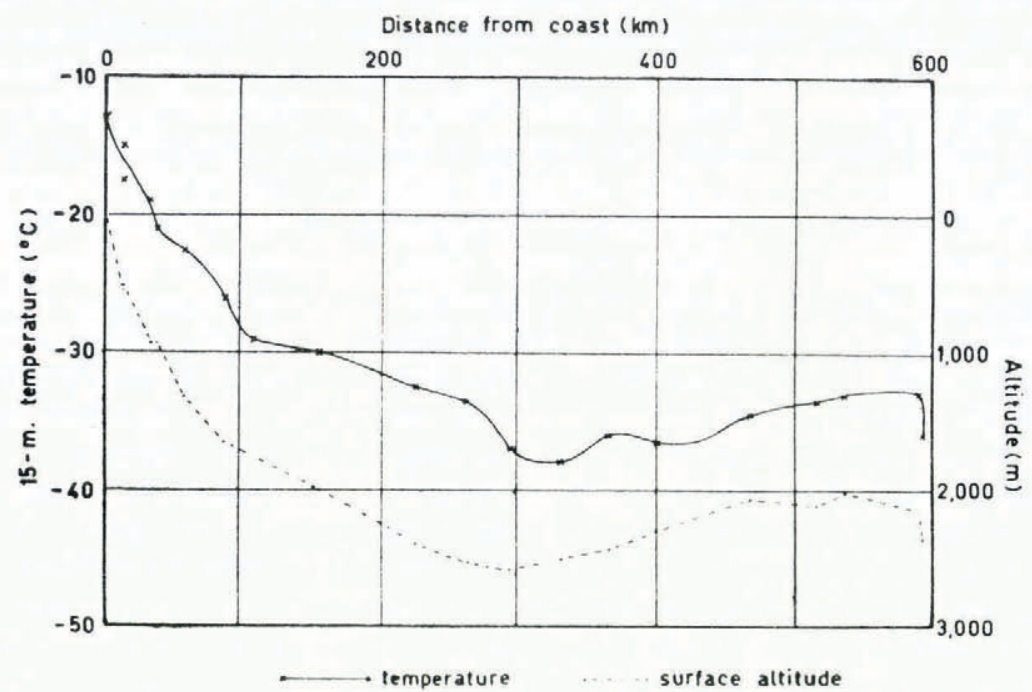

Fig. 5. Variation of ice temperature $15 \mathrm{~m}$. below the surface with distance from the coast

Coming next to the temperatures inside the ice sheet, it is found that all the profiles show a fall of temperature with increase of depth below the $15 \mathrm{~m}$. level, i.e. all the gradients are negative. The gradients lie in the range $-1^{\circ}$ to $-7^{\circ} \mathrm{C}$. per $100 \mathrm{~m}$. depth, and agree broadly with measurements from other regions, as set out in Table I.

\section{Place}

(a) Greenland

"Eismitte"

"Station Centrale"

Camp 6

SIPRE Site II

,,

(b) Antarctica

$5 \mathrm{~km}$. south of "Mirnyy"

$\begin{array}{cc}\text {, } & ,, \\ 50 \mathrm{~km} . & , \\ 150 \mathrm{~km} . & , \\ 225 \mathrm{~km} . & , \\ \text { Berd Station } & \end{array}$

Byrd Station'

"Southice""

Ice sheet south of Mawson

Table I. Temperature Gradients in Icie Shitets

\section{Reference}

Sorge ${ }^{3}$

Heuberger ${ }^{4}$

$$
\text { , }
$$

Hansen \& Landauer 5

,

Bogoslovski ${ }^{2}$

,,
,,
,,
",
Wexler

Stephenson and Lister ?

Mellor
Depth range

$\mathrm{m}$.

$10-15$
$20-50$
$60-90$
$20-50$
$10-90$
$150-400$

$10-40$
$20-100$
$300-400$
$10-70$
$10-60$
$10-50$
$10-45$
$80-300$
$20-45$
$10-30$

Mean temperalure gradient C. $100 \mathrm{~m}$.

$$
\begin{aligned}
& -3 \cdot 4 \\
& -\mathrm{I} \cdot 5 \\
& -0 \cdot 7 \\
& -4 \cdot 3 \\
& -\mathrm{I} \cdot 2 \\
& -0 \cdot 1
\end{aligned}
$$

$$
\begin{array}{r}
-3 \cdot 4 \\
-1 \cdot 8 \\
+4 \cdot 8 \\
-2 \cdot 4 \\
-1 \cdot 2 \\
-0 \cdot 8 \\
+1 \cdot 3 \\
-0 \cdot 1 \\
0 \\
-1 \cdot 3 \text { to }-7 \cdot 1
\end{array}
$$

From this table it can be seen that, in polar ice sheets, there is generally a negative temperature gradient of the order of $2^{\circ} \mathrm{C}$. $/ 100 \mathrm{~m}$. in the upper $50 \mathrm{~m}$. of the ice, the only 
exception being the positive gradient down to $45 \mathrm{~m}$. at Byrd Station.* The gradient becomes smaller at greater depths, and it appears that the reversal of slope might occur at a depth of a few hundred metres.

\section{Theories on Negative Gradients}

The existence of negative temperature gradients is puzzling in view of the upward geothermal heat flux and the release of frictional heat in the ice. The explanation offered by Sorge, ${ }^{3}$ who was the first to observe the negative gradient, was based on climatic change, gradual warming of the air over the ice sheet leading to deposition of succeeding firn layers at higher and higher temperatures. This seemed a reasonable explanation at the time, for there was ample evidence of an amelioration of climate in the Arctic. When the French measurements at "Station Centrale," close to the original site of "Eismitte," became available ${ }^{4}$ Georgi established a correlation between Sorge's temperatures and the new profile and concluded that climatic change indeed provided the true explanation of the phenomenon. ${ }^{8}$ This was, however, disputed by Loewe 9 who showed that, owing to conduction, Sorge's anomaly could not have persisted for more than a few years in the form assumed by Georgi. Loewe's assumption of an instantaneous temperature rise followed by constant temperatures is not, however, a good approach to persistent climatic changes.

In the case of Antarctica, there is no definite indication of glacial retreat and only slight evidence of contemporary secular warming. ${ }^{17}$ Heat conduction theory suggests that warming would have to be continuous for long periods in order to develop throughout the uppermost $400 \mathrm{~m}$. the almost constant negative temperature gradients which have now been observed there, and over this length of time the ice would move from its initial point of origin into regions of lower surface altitudes where the annual mean temperatures are somewhat higher. This being so, it seems preferable to examine first the effect of this increase of surface temperature due to downward movement of the ice before discussing climatic warming.

Robin ${ }^{\text {II }}$ considered the case of surface warming by ice flow on the assumption that heat conduction is negligible. For the temperature gradient close to the surface he derived the expression

$$
\frac{d T}{d x}=\frac{V \sin \alpha \lambda}{v} \sim \frac{V \alpha \lambda}{v}
$$

where $T$ is the temperature, $x$ the depth in the ice sheet, $V$ the surface velocity of the ice, $\alpha$ the surface slope of the ice sheet, $\lambda$ the rate of change of mean air temperature with altitude and $v$ is the rate of accumulation of ice at the surface (which is equivalent, near the surface, to the downward velocity of a given layer relative to the surface).

Robin's theory was a major step forward, but neglect of conduction is clearly not justifiable when long time intervals are involved. Bogoslovski considered the temperature distributions separately brought about by each of four simple conduction processes, eventually employing the principle of superposition to give the resultant gradient near the surface. The most important effect was found to arise from the horizontal motion of the ice.

However, Bogoslovski's assumed stationary heat conduction state may not be realistic in this case, since it is not approached in the limit as time increases. This was pointed out by Radok ${ }^{\text {Io }}$ who suggested an alternative approach based on the assumption that horizontal temperature gradients in an ice sheet are uniform over horizontal distances large compared with the thickness of the ice sheet. The use of a coordinate system moving with the ice then reduces the conduction problem to the linear case, governed by the differential equation

$$
K \frac{\partial^{2} T}{\partial x^{2}}-v \frac{\partial T}{\partial x}-\frac{\partial T}{\partial t}=0
$$

* The profile presented by Wexler shows a positive gradient down to $45 \mathrm{~m}$., but when measurements were first made in February $195^{8}$ there was a negative gradient to that depth. ${ }^{18}$ 
where $K$ is the thermal diffusity and $t$ the time, while the remaining symbols have their previous meanings.

Robin used a similar argument in his analysis of conditions at the French Camp 6 in Greenland, but since he put $v$ proportional to depth considerable mathematical complexity was introduced and a solution was not reached. Instead, the differential equation can be fitted to an observed profile numerically, but whilst this method provided an apparently reasonable value for the horizontal velocity of the ice, Robin has pointed out (private correspondence) that the attempt to derive the rate of accumulation from the temperature profile is unrealistic in view of the other factors involved.

Equation (3) has been solved by Benfield ${ }^{12}$ for the boundary and initial conditions of interest here, and a formula given by him for the temperature gradient in a rock mass subject to uplift and denudation ${ }^{13}$ is easily modified to fit the case of an ice sheet receiving surface accumulation and descending. ${ }^{\text {Io }}$ The equation becomes

$$
\begin{aligned}
\frac{\partial T}{\partial x}(x, t)=A & -\frac{\mathrm{I}}{2}\left(A+\frac{\beta}{v}\right)\left[\operatorname{erfc}\left\{\frac{x-v t}{(4 K t)^{\frac{1}{2}}}\right\}+2 v\left(\frac{t}{\pi K}\right)^{\frac{1}{2}} \exp \left\{-\frac{(x-v t)^{2}}{4 K t}\right\}-\right. \\
& \left.-\left\{\mathrm{I}+\frac{v(x+v t)\}}{K}\right\} \exp \left(\frac{v x}{K}\right) \operatorname{erfc}\left\{\frac{x+v t}{(4 K t)^{\frac{1}{2}}}\right\}\right]
\end{aligned}
$$

where $A$ is the initial temperature gradient, $\beta=V \alpha \lambda$ is the rate of temperature increase due to downhill flow and other symbols retain the meanings of equations (2) and (3).

When $K \rightarrow$ o, i.e. when conduction is negligible, equation (4) reduces to Robin's equation; but the equation also reduces to this simple form when $t \rightarrow \infty$. This is linked with the fact that the heat conduction equation for a moving medium (3) has the simple linear solution

where $\beta$ is a constant. ${ }^{\mathrm{I}}$

$$
T=\beta\left(t-\frac{x}{v}\right)
$$

Preliminary calculations based on (3) for representative values of accumulation, slope, and ice velocity have shown that, starting from isothermal conditions, the gradient down to the $100 \mathrm{~m}$. level exceeds 70 per cent of its limiting value (2) after 5,00o years. In this time the ice has moved no more than roo km., or a distance over which the assumption of constant ice flow conditions is not unreasonable. Thus there is now a firm justification for the adoption of Robin's equation in the consideration of temperature profiles close to the surface of a thick ice sheet.

In the next section Robin's equation is used to deduce ice flow velocities from the temperature gradients, surface slopes, accumulation rates and surface temperature lapse rates for some of the points along the $1957-58$ seismic traverse from Mawson. These velocities are then compared with independent velocity estimates based on measured ice flow rates across the coast of MacRobertson Land and the ice depths inland.

\section{Ice Velocity Estimates}

From ice flow measurements in MacRobertson Land ${ }^{15}$ it has been calculated ice moves at the rate of $6.5 \times 10^{12} \mathrm{~g} . / \mathrm{km} . \mathrm{yr}$. across a coast which is free from shelf ice but which has Io per cent of its length occupied by ice streams. From continuity considerations it is therefore possible to estimate inland ice velocities provided that ice depths are known. However, for the region under consideration here the picture is complicated by the fact that the inland ice south of Mawson flows not only across the coast to its north but also eastward into the Lambert Glacier and the Amery Ice Shelf (see Fig. I). Further, the ice flow quantities originally estimated from velocity measurements are now considered to be on the low side, after a study of the mass balance of the ice sheet. ${ }^{\mathrm{I}}$ It is therefore felt that the mass flow figure quoted above should be multiplied by a factor of 2 to give a better approximation for the 
mass flow of the inland ice, which would then become $13 \times 10^{12} \mathrm{~g} . / \mathrm{km}$.yr. If the mean density of the ice is taken as $0.87 \mathrm{~g} . / \mathrm{cm} .^{3}$, the surface velocity of the inland ice (where viscous shear is small) is given approximately by

$$
v_{2}=\frac{\mathbf{I} \cdot 5 \times 10^{4}}{h} \mathrm{~m} \cdot / \mathrm{yr} .
$$

where $h$, the ice depth, is measured in metres.

Ice depth measurements made by Goodspeed ${ }^{16}$ have been used to estimate by means of equation (6) surface velocities at a number of points where temperature profiles were taken, assuming the major protuberances to be ridges rather than isolated peaks (observations tend to justify this assumption). Next, measured temperature gradients have been substituted into Robin's equation (2) together with known values of surface slope, accumulation, and temperature lapse rate. In this way the ice velocity has again been computed and the two values of velocity for each of the points treated are given in Table II. South of lat. $70^{\circ}{ }^{\prime} 3^{\prime} \mathrm{S}$. the slopes run in an easterly direction and the gradients are not yet known. This information should become available when radar altimeter heighting is carried out in that area.

Table II. Velocity of Flow of the Ice Sheet

\begin{tabular}{|c|c|c|c|c|c|c|c|c|}
\hline $\begin{array}{l}\text { Latitude } \\
\quad S .\end{array}$ & $\begin{array}{c}\text { Altitude } \\
\mathrm{m} .\end{array}$ & $\begin{array}{c}\text { Measured } \\
\text { gradient } \\
{ }^{\circ} \mathrm{C} . / 100 \mathrm{~m} .\end{array}$ & $\begin{array}{l}\text { Surface } \\
\text { slope, } \alpha \\
\text { degrees }\end{array}$ & $\begin{array}{c}\text { Tempera- } \\
\text { ture } \\
\text { lapse rate } \\
{ }^{\circ} \mathrm{C} . / 100 \mathrm{~m} .\end{array}$ & $\begin{array}{l}\text { Accumula- } \\
\text { tion, } v \\
\text { m. of ice }\end{array}$ & $\begin{array}{c}\text { Calculated } \\
\text { velocity, } V_{\mathrm{I}} \\
\text { from equation }(2) \\
\mathrm{m} \cdot / \mathrm{yr} .\end{array}$ & $\begin{array}{l}\text { Ice } \\
\text { depth, } \\
h \\
\text { m. }\end{array}$ & $\begin{array}{c}\text { Calculated } \\
\text { velocity, } V_{2}, \\
\text { from mass flow } \\
\text { m./yr. }\end{array}$ \\
\hline $68^{\circ} 07^{\prime}$ & 1312 & $-4 \cdot 0$ & $14 \times 10^{-3}$ & $3 \quad I \cdot O$ & 0.20 & 570 & 900 & 17 \\
\hline $68^{\circ} 25^{\prime}$ & 1649 & $-4 \cdot 4$ & $7 \cdot 6 \times 10^{-3}$ & $I \cdot I$ & 0.15 & 790 & $155^{\circ}$ & Io \\
\hline $68^{\circ} 33^{\prime}$ & $175^{6}$ & $-1 \cdot 5$ & $2.7 \times 10^{-3}$ & $I \cdot I$ & 0.25 & I30 & 1500 & 10 \\
\hline $68^{\circ} 59^{\prime}$ & I999 & $-2 \cdot 6$ & $3.0 \times 10^{-3}$ & $I \cdot 2$ & 0.25 & 180 & $155^{\circ}$ & 10 \\
\hline $69^{\circ} 3^{8^{\prime}}$ & 2389 & $-2 \cdot 9$ & $4.9 \times 10^{-3}$ & I. 3 & 0.30 & 140 & 1500 & 10 \\
\hline $69^{\circ} 55^{\prime}$ & 2525 & $-7 \cdot 1$ & $2.5 \times 10^{-3}$ & $1 \cdot 3$ & 0.30 & 660 & 250 & 60 \\
\hline $70^{\circ} 15^{\prime}$ & 2582 & $-5 \cdot 0$ & $13 \times 10^{-3}$ & $I \cdot 3$ & 0.30 & 90 & 2250 & 7 \\
\hline $70^{\circ} 31^{\prime}$ & 2449 & $-1 \cdot 7$ & & & & & & \\
\hline $71^{\circ} 08^{\prime}$ & 2299 & $-3 \cdot 3$ & & & & & & \\
\hline $71^{\circ} 46^{\prime}$ & 2074 & $-1 \cdot 7$ & & & & & & \\
\hline $7^{2} \quad 13$ & 2113 & $-1 \cdot 3$ & & & & & & \\
\hline $72^{\circ} 22^{\prime}$ & 2090 & $-1 \cdot 7$ & & & & & & \\
\hline
\end{tabular}

\section{Discussion of Table II}

The velocities $V_{\mathrm{I}}$ calculated from equation (2) are seen to be an order of magnitude higher than the $V_{2}$ values estimated from continuity considerations. The only factor which could produce a gross error in $V_{2}$ is an incorrect value of temperature gradient $\frac{d T}{d x}$, but the magnitudes of the measured gradients are in agreement with results from other areas, so that there is little point in discussing the accuracy of the temperature measurements in detail. The velocities $V_{2}$ are believed to be of the right order; the only values which could be magnified with any justification are the first two, proximity of these stations to the Framnes Mountains possibly placing them in an area of locally accelerated flow.

Reverting to the discussion of temperature gradients, the evidence of Table II seems to show that, if realistic velocities are taken, gradients produced by the Robin effect are an order of magnitude smaller than those which have been measured.

It therefore becomes necessary to consider the possible effects of climatic change on the upper layers of the Antarctic Ice Sheet.

\section{Climatic Change}

In Greenland, climatic warming during the past 50 years is well substantiated and it is reasonable to suppose that temperature gradients in the upper layers of the ice sheet have been affected by the change. Robin ${ }^{\text {II }}$ found that his gradients computed from equation (2) 
were one-tenth and one-half of the observed gradients at the French "Station Centrale" and Camp VI respectively, and this suggests some additional effect. At the U.S. Site II in northwest Greenland, measurements indicate more strongly that the Robin effect is of minor importance; no movement has been detected in five years, surface slopes are very slight, but there is a gradient of $-\mathrm{I} \cdot 2^{\circ} \mathrm{C}$. $/ 100 \mathrm{~m}$. down to $90 \mathrm{~m}$. depth. The $15 \mathrm{~m}$. ice temperature at Site II apparently rose by $2 \cdot \mathrm{I}^{\circ} \mathrm{C}$. in the five years from I954 to I959 and the negative gradient became steeper (personal communication from Mr. Lyle Hansen). [However, the mean annual air temperature dropped $0.3^{\circ} \mathrm{C}$. from July i 953 to July i 956 ; only i i months observations were made the following year, but addition of a three-year average value for the missing month indicates that the mean temperature for $1956-57$ was the same as for I953-54, i.e. there had been no significant change up to r957.]

Table III. Chimatic Change in Greenland and Antarctica

\section{Location}

Ivigtut, Greenland 19

Godthaab, Greenland 19

Angmagssalik, Greenland 19

Jakobshavn, Greenland 19

Upernavik, Greenland 19

"Eismitte"-_"Station Centrale"

Site II, north-west Greenland

Bay of Whales, Antarctica

, , ",

", ,
Period

I 90 I -20 to $1921-40$

I $901-20$ to $1921-36$

I 90 I -20 to I $92 \mathrm{I}-40$

I $90 \mathrm{I}-20$ to $192 \mathrm{I}-40$

I $901-20$ to $1921-36$

1931 to $195^{\circ}$

I954 to 1959

I 9 I I to I 929

1929 to 1940

I 940 to 1957

Temperature change
${ }^{\circ} \mathrm{C}$.
+0.6
$+\mathrm{I} \cdot 3$
$+\mathrm{I} \cdot 6$
$+\mathrm{I} \cdot 8$
+3.1
$+\mathrm{I} \cdot 2$
$+2.1 \%$
+0.8
+0.2
+2.0

Rate of change

${ }^{\circ} \mathrm{C} . / \mathrm{yr}$.

$+0.03$

$+0.07$

$+0.08$

$+0.09$

$+0.16$

$+0.06$

$+0.42^{*}$

$+0.04$

$+0.02$

$+0.12$

* Possible misinterpretation of readings. The 1954 firn temperature was measured in a pit; the 1957 reading was taken in a borehole. Pit wall temperatures may be depressed by an uncompensated winter inflow of cold air.

In the southern hemisphere the retreat of temperate glaciers and changes at Heard Island ${ }^{17}$ suggest that there has been a recent climatic change corresponding to that in the north, but there are no reliable supporting data from Antarctica. Temperature observations made by early expeditions are awkward to compare with modern measurements unless the exact site has been re-occupied, but temperatures on the Ross Ice Shelf near the Bay of Whales do seem to have risen since Amundsen's stay in I9I I. The mean annual temperature at Little America V in 1957 was $3^{\circ} \mathrm{C}$. higher than that recorded at Framheim in I9I I, and $2^{\circ}$ C. higher than the temperature at Little America III in 1940.

Table III shows rates of warming for various Greenland stations and for the Ross Ice Shelf. The values generally range from $+0.02^{\circ}$ C. to $+0 \cdot 16^{\circ} \mathrm{C}$. per year, with one exceptional figure of $+0.4^{\circ} \mathrm{C}$./yr. at Site II.

The conduction equation can be solved analytically for the case where surface temperature is a function of time, but, where computers are available, numerical methods constitute a more powerful approach to the problem of changing surface temperature. Numerical techniques permit complications such as the change of conductivity with depth to be taken into account. Jenssen and Radok (private communication) treated the case of rising surface temperature on a moving, accumulating ice sheet $\mathrm{I}, 500 \mathrm{~m}$. thick at the point considered. After 5,00o years of conduction without climatic change the Robin effect produced a gradient of the order of $-0.3^{\circ} \mathrm{C}$. $100 \mathrm{~m}$. down to about $200 \mathrm{~m}$. depth, and the surface temperature was $-3 \mathrm{I}^{\circ} \mathrm{C}$. A surface temperature increase of $\mathrm{I}^{\circ} \mathrm{C}$. in 50 years was imposed and, in 50 years, the gradient between Io and $35 \mathrm{~m}$. depth changed from $-0.35^{\circ} \mathrm{C}$. $/$ i $00 \mathrm{~m}$. to about $2 \cdot 4^{\circ} \mathrm{C}$. $/$ roo $\mathrm{m}$. Full details will be published by Jenssen and Radok.

Close to the surface of a thick ice sheet the temperature profile is sensitive to climatic change and the numerical calculation above shows that gradients similar to the observed ones are produced by fairly realistic assumptions regarding extent and duration of warming. 
Thus it seems that climatic change best explains the temperature distribution in the upper layers.

\section{ACKNOWLEDGEMENTS}

The author is very grateful for the advice of Dr. Uwe Radok throughout this work, and for the invaluable guidance of Dr. F. Loewe. He would like to thank his colleagues of the r 957-58 A.N.A.R.E. seismic team for their help in the field, and also Dr. G. de Q. Robin for correcting and commenting on the original draft.

MS. received 3 February 1960

\section{REFERENCES}

I. Mellor, M. A study of factors governing the mass economy of Antarctica. Thesis, University of Melbourne, 1959 .

2. Bogoslovski, V. N. The temperature conditions (regime) and movement of the Antarctic glacial shield. Union Géodésique et Géophysique Internationale. Association Internationale d'Hydrologie Scientifique. Symposium de Chamonix, 1958, p. 287.

3. Sorge, E. Glaziologische Untersuchungen in Eismitte. (In Brockamp, B., and others. Glaziologie. Leipzig, F. A. Brockhaus, 1935, p. 263. (Wissenschaftliche Ergebnisse der Deutschen Grönland-Expedition Alfred Wegener 1929 und $1930 / 31$, Bd. 3.))

4. Heuberger, J.-C. Glaciologie. Groenland. Vol. I: forages sur l'inlandsis. Paris, Hermann, I954. (Actualités scientifique et industrielles, I 2 I 4. Expéditions Polaires Françaises [travaux], 5.)

5. Hansen, B. L., and Landauer, J. K. Some results of ice cap drill hole measurements. Union Géodésique... . Symposium de Chamonix [cf. ref. 2], 1958, p. 313.

6. Wexler, H. Geothermal heat and glacial growth. Journal of Glaciology, Vol. 3, No. 25, 1959, p. 420.

7. Stephenson, P. J., and Lister, H. Preliminary results of the glaciological work on the Trans-Antarctic Expedition, I 955-58. Fournal of Glaciology, Vol. 3, No. 25, 1959, p. 426.

8. Georgi, J. Temperatur- und Dichtemessungen des grönländischen Inlandeises. Annales de Géophysique, Tom. 12, No. I, 1956, p. 102.

9. Loewe, F. Remarques concernant des mesures de température et d'accumulation sur l'inlandsis groenlandais. Annales de Géophysique, Tom. 13, No. 2, 1957, p. 158.

10. Radok, U. Temperatures in polar ice caps. Nature, Vol. 184 , No. 4692 , 1959, p. 1056.

I I. Robin, G. de Q. Ice movement and temperature distribution in glaciers and ice sheets. Fournal of Glaciology, Vol. 2, No. 18, 1955, p. 523.

12. Benfield, A. E. A problem of the temperature distribution in a moving medium. Quarterly of Applied Mathematics, Vol. 6, 1949, p. 439.

13. Benfield, A. E. The effect of uplift and denudation on underground temperatures. Fournal of Applied Physics, Vol. 20, 1949, p. 66.

14. Jaeger, J. C. Personal communication to U. Radok, 1959.

15. Mellor, M. Ice flow in Antarctica. Journal of Glaciology, Vol. 3, No. 25, 1959, p. 377.

16. Goodspeed, M. J. Preliminary report on measurements of ice thickness on the Antarctic ice cap by seismic and gravimetric methods. Australia. Dept. of National Development. Bureau of Mineral Resources, Geology and Geophysics, Records, No. 40, 1958.

17. Mellor, M. Variations of the ice margins in East Antarctica. Geographical fournal, Vol. 125, Pt. 2, 1959, p. 230.

18. Ragle, R. H., and others. Deep core drilling in the Ross Ice Shelf. U.S. Snow, Ice and Permafrost Research Establishment. Technical Report 70, 1959.

19. Diamond, M. Air temperature and precipitation on the Greenland Ice Sheet. Fournal of Glaciology, Vol. 3, No. 27,1960, p. 564 . 